ISSN 2078-6441. Вісник Львівського університету. Серія географічна. 2014. Випуск 47. С. 115-123. Visnyk of the Lviv University. Series Geography. 2014. Issue 47. P. 115-123.

911.3:32

иросл в ністрянський

ьвівський н ціон льний університет імені в н вул. . орошенк, 41, 79000, м. ввів, кр їн

икон но критичний н ліз понятійно-термінологічного п р ту суч сної геополітики, обгрунтов но пропозиції його вдоскон лення. иділено п р дигми н укового н лізу глоб льних геополітичних процесів. озкрито основні суч сні глоб льно-політичні тенденції. бгрунтов но 3 кономірність утворення т зміни цивіліз цій-культур. изн чено суттєві зв'язки і з лежності в геополітичному устрої світу. озкрито з кономірний х р ктер зближення територі льної орг ніз ції політичної т етнон ціон льної сфер суч сного світу. иділено хибні методологічні підходи до н лізу геополітичної ситу ції в кр їні.

лючові слов : геополітик, об'єктивний геополітичний н ліз, методологія геополітики, концепту льні основи геополітики, геополітичні тенденції.

еополітик сьогодні м є б г тозн чний х р ктер, включ ючи і систему н укових зн нь т філософських поглядів щодо просторової впорядков ності й зумовленості політичного світоустрою, і сукупність прикл дних підходів щодо перспектив тр нсформ ції й оптиміз ції політичного простору в процесі пр ктичної діяльності всіх суб'єктів. структурою геополітичної інформ ції виділяємо три скл дові геополітики - геополітик як н уков н літик, геополітичн філософія т пр ктичн геополітик .

огляду н несформов ність теоретико-методологічних основ н йскл дніше відбув ється процес формув ння геополітики як н укової дисципліни. ині ще передч сно ст вити пит ння про створення її стрункої концепції, може йтися лише про обгрунтув ння б зових принципів стосовно дослідження окремих спектів орг ніз ції політичного життя $з$ позицій геопростору, які могли 6 з кл сти основу відповідних п р дигм н укового геополітичного н лізу. обто у визн ченні стр тегії н укового геополітичного н лізу першорядним є концепту льне осмислення окремих проблем у поєдн нні 3 конкретиз цією методології відповідних н укових досліджень.

скільки пр ктичн геополітик висунул низку понять і термінів, які з пізн в льних т політично-етичних позицій не декв тно х р ктеризують різні геополітичні феномени, то розгляд концепту льно-методологічних проблем н укового геополітичного н лізу доцільно розпоч ти з виділення прикл дів невідповідного використ ння понятійно-термінологічного п р ту. е стосується, н прикл д, диференці ції суб'єктів геополітичних вз ємин, коли, зокрем , для озн чення одних використовують термін “геополітичні гр вці”, інших - “геополітичні осі” [1], виділяючи цим ім нентну винятковість перших і повну п сивність других. к с мо неприйнятним є використ ння в геополітичному н лізі термін “суперетнос", який . умільов використ в для х р ктеристики різних історичних феноменів [2]. ьогодні цей термін з стосовують для позн чення різних великих територі льних груп н селення, сутність яких ф ктично

(C) ністрянський ., 2014 
не м є нічого спільного з природою етнон ціон льних спільнот (н прикл д, євр зійський суперетнос, $p$ дянський суперетнос, слов'янський суперетнос т ін.), дже в цьому p зі з кл д ють і обгрунтув ння різних моделей експ нсії. овляв, якщо є євр зійський суперетнос, то чому не бути євр зійській н ддерж ві? к с мо невипр вд ним є озн чення суч сних рівнопр вних суб'єктів міжн родних відносин як “лімітрофи” [13], під якими розуміють окр їнні прид тки великих держ в. к не прикро, цей термін 3 російськими н логіями поч ли некоректно з стосовув ти й укр їнські політологи [8]. ому н голосимо, що використ ння т ких термінів, які не м ють когнітивного зн чення, свідчить н с мперед про з нг жов ність вторів у різні великодерж вницькі проекти.

пр гненні сформув ти понятійно-термінологічний п р т т б зові геополітичні 3 кономірності іноді н зив ють т к зв ний з кон пл нет рного ду лізму, який стверджує про нібито постійний ім нентний нт гонізм "цивіліз цій суходолу" (телурокр тіі) і “цивіліз цій моря" (т л сокр тії). е положення ст ло популярним після виходу в світ пр ці . ккіндер (1861-1947) “ еогр фічн вісь історії” (1904) [7]. ринципово з перечуючи цю ідею, з зн чимо, що н віть виділення суто морських і суто суходільних суспільств (цивіліз цій) не з вжди є методологічно коректним, дже всі цивіліз ції т к чи ін кше сформув лися в меж х суходолу, $б$ г то кр їн безпосередньо поєднув ли приморські регіони і континент льні. р диційне природокористув ння, доіндустрільне господ рство узбереж т континент льних р йонів вр зії спр вді суттєво відрізнялися, н кл д ючи особливий відбиток н м тері льну і духовну культуру 3 г лом, т все ж нем підст в говорити, що сум рно вони з кл д ють якесь протистояння. ільшу диференці цію геокультурних відмінностей і особливостей політичного мент літету розкрив є етногеогр фічний підхід, який з цією схемою ф ктично цілком ігнорують. обто вл сне геогр фія н родів, їхня культурно-мент льн близькість і визн чил конфігур цію цивіліз цій-культур, їхні суттєві відмінності. ур хув нням цих т б г тьох інших ргументів є всі підст ви для висновку: модель пл нет рного ду лізму - нен уковий підхід, деструктивн міфологем , що перешкодже є формув нню оптим льної глоб льної територі льно-політичної орг ніз цї світу, оскільки прогр мує невмотивов не, перев жкно цілком безпідст вне протистояння $m$ нт гонізм різних ч стин світу. ідповідно, поняття т терміни, сформов ні в $\mathrm{p}$ мк $\mathrm{x}$ ідеології протистояння т л сокр тія-телурокр тія, у тому числі й для позн чення геополітичного зн чення різних ч стин світу (“х ртленд”, “внутрішній півмісяць”, “рімленд”, “світовий острів”), можн використовув ти лише для х р ктеристики історичного геополітичного мислення, т ж ніяк не для оцінки суч сної геополітичної орг нізов ності світу.

тже, у процесі впорядкув ння понятійно-термінологічного п р ту геополітики як к демічної дисципліни необхідно н с мперед сформув ти струнку систему понять для озн чення геополітичного устрою (геополітичної впорядков ності) світу, який розгляд ємо як просторове відобр ження геополітичних суб'єктів, центрів впливу $m$ смуг геополітичної вз ємодї. с дниче зн чення для х р ктеристики геополітичного світоустрою м є систем розроблених у р мк х політичної геогр фії понять і термінів (територі льн орг нізов ність (упорядков ність) політичної сфери, політичний простір, політичні межі й політичні центри, держ вн територія і держ вний кордон, держ вно-територі льний устрій, політико-геогр фічне положення і політикогеогр фічний процес т ін.), яку доцільно доповнити вже уст леними спеці льними поняттями геополітики (геополітичне положення, геополітичний центр, геополітичні 
відношення, геополітичний інтерес, геополітичн вз ємодія, геополітичн історія, геополітичний конфлікт т ін.) [6]. онструктивними $€$ й деякі інші пропозиції розширення понятійно-термінологічного п р ту геополітики, обгрунтов ні політикогеогр ф ми. прикл д, для х р ктеристики геополітичного устрою держ ви . ценко 3 пропонув в т кож поняття геопросторовий $\kappa р \kappa c$ держ ви, який, н його думку, формують столиці, дміністр тивні центри вищого рівня, пов'яз ні тр нспортними коридор ми, і який може м ти різну конфігур цію (лінійну, деревоподібну, зіркоподібну, ортогон льну) [9, с. 104].

ля потреб н укового геополітичного н лізу в жливо теж понятійно окреслити коло суб'єктів геополітики, які є уч сник ми територі льно-політичних вз ємин i формують структуру політичного простору. ьогодні т кі суб'єкти - це держ ви, територі льно-політичні втономії, з лежні кр їни і с мопроголошені держ ви, релігійні центри, політичні п ртії, етнополітичні й релігійно-політичні рухи, міжн родні орг ніз ції і міжн родні територі льно-політичні об'єдн ння, тр нсн ціон льні корпор ції. визн ченні зн чущості суб'єктів геополітики, перспектив геополітичної орг нізов ності з г лом ключове зн чення м ють т кі поняття, як геополітичне положення, геополітичні відношення, геополітичний потенці л, поле (смуг ) геополітичної вз ємодії, геополітичний процес. кщо розгляд ти держ ву як основний суб'єкт міжн родних відносин i, відповідно, геополітики, то їі геополітичне положення - це вся сукупність територі льних $i$ політичних відношень до природно- $i$ суспільногеогр фічних об'єктів, що перебув ють поз його меж ми, у контексті перев г $i$ недоліків з безпечення зовнішніх $і$ внутрішніх н ціон льно-держ вних інтересів, цілісності $m$ поступ льного розвитку. структурі територі льних відношень суттєвими є н с мперед відношення близькості й відд леності, сусідств . н чно ширшим є спектр геополітичних відношень, тобто системи політичних зв'язків, що $\epsilon$ геопросторово зумовленими бо м ють геопросторові виміри (з лежності і вз ємоз лежності, впливу і вз ємовпливу, тяжіння, п ртнерств й конфліктності т ін.). тже, геополітичне положення, яке охоплює кількісні т якісні х р ктеристики, окреслює позиційність одних суб'єктів геополітики стосовно інших, виявляючи в жливі співвідношення н геополітичній к рті світу.

еополітичн позиційність держ в безпосередньо пов'яз н 3 політикогеогр фічними вл стивостями ї̈ держ вної територї̈, з ур хув нням, зокрем , того, як і н 3 с д х яких принципів вон сформув л ся, якими є їі п р метри, природноресурсний потенці л, етногеогр фічн, релігійно-геогр фічн т п ртійно-політичн структур , соці льно-економічн освоєність. огляду н це поєдн ння геополітичного положення держ ви з вл стивостями їі держ вної території, особливостями геополітичної історії т історично-геополітичними тр диціями (перев жний тип геополітичної свідомості т геополітичного мислення, геополітичні симп тії й нтип тії, консолідов н геополітичн воля суспільств до утвердження своєї цілісності й місця н к рті світу тощо) формує своєрідний геополітичний обр з (портрет) держ ви, який $\epsilon$ в жливою скл довою їі геополітичного потенці лу, інші чинники якого - культурноінформ ційн, економічн т військов могутність. тже, геополітичний потенці л держ в є результ том сукупної дії т єдності просторово-ч сових чинників і, відповідно, м є просторово-ч сові виміри. ін суттєво вплив є н їхню пр ктичну геополітику т х р ктер вз ємодії 3 іншими держ в ми, н слідком якої $є$ формув ння полів вз ємодіï, які . т фійчук визн ч $є$ як “виокремлений н основі поєдн ння (н кл д ння) геостр тегій з інтересов них кторів сегмент суспільної діяльності, який вз ємодіє 
з певним геогр фічним простором" [9, с. 148]. з ємодія і вз ємозв’язки всієї сукупності суб'єктів геополітики н певній території формують їі геополітичне середовище.

р ктер вз ємодії суб’єктів геополітики визн ч ють їхні геополітичні інтереси.

н уковому геополітичному н лізі в жливо відділити об'єктивні геополітичні інтереси, ре ліз ція яких не з грожує іншим суб'єкт м іє передумовою поступ льного розвитку, від ідеологічно-деструктивних т гресивних геопросторових претензій, які м ють потенці л конфліктності. прикл д, для держ в об'єктивні геополітичні інтереси - це сукупність життєво в жливих потреб, що пов'яз ні зі збереженням іхнього суверенітету, територі льної цілісності, зрост нням потенційних можливостей і визн чені всім комплексом геогр фічних чинників (розміщенням н к рті світу, природними умов ми і ресурс ми, відношеннями сусідств і відд леності т ін.). одноч с пр гнення держ в до гегемонії, з хоплення територій інших держ в чи обмеження геогр фічних передумов їхньої життєдіяльності не може не суперечити їхнім інтерес м, провокуючи конфліктні ситу ції. ому формув ння т ре ліз ція геостр тегії узгоджкення інтересів різних суб'єктів геополітики - н йбільш кту льне з вд ння ін укової н літики, і пр ктичної геополітики.

еополітичний устрій світу вирізняється помітною дин мічністю. мін структури політичного простору т х р ктеру вз ємодії відбув ється через геополітичні процеси, прикл д ми яких н глоб льному рівні $є$ формув ння полюсів політичного впливу різного рівня ієр рхії, н держ вному - процеси територі льно-політичної консолід ції чи, н вп ки, поляриз ції, регіон льного відчуження.

ст новленні геополітики як н укової н літики н йскл днішим є відбір вихідних концепту льних положень т методологічних підходів. кі принципи м ють грунтув тися н пізн нні з кономірних тенденцій походження, формув ння й розвитку різних скл дових політичного простору, т кож н виявлених з кономірностях структурної орг ніз ції політичної сфери $m$ вз емодї̈ різних територі льно-політичних структур. окрем, у другій половині -н поч тку ст. у соці льно-політичному житті людств, попри велику різном нітність нових політичних чинників, дост тньо рельєфно виявились дві протилежні тенденції- глоб ліз ція й сувереніз ція, різновекторність яких $і$ визн ч $е б$ г то суч сних геополітичних суперечностей [4, с. 48]. і тенденції х р ктерні не лише безпосередньо для політичних вз ємин, й для інших сфер життєдіяльності людського суспільств (соці льної, культурної, економічної, інформ ційної), які т к чи ін кше торк ються політичних вз ємин. тже, поглиблення економічної т комунік ційної пов'яз ності, екологічної т політичної вз ємоз лежності, поширення стереотипів м сової культури, тенденції до уніфік ції соці льної сфери усе це суперечливо поєднується з пр гненням держ в т н родів зберегти політичну й економічну нез лежність т етнокультурну с мобутність.

опри н явність двох тенденцій, все ж можн виявити помітне домінув ння однієї з них у певних сфер х, міжн родних регіон х т впродовж якогось ч сового проміжку.

прикл д, у геоекономічній сфері виявом процесів сувереніз ції т помірков ної економічної вт ркіз ції $є$ жорстк конкуренція 3 ринки збуту і безкомпромісний з хист держ в ми своїх н ціон льних інтересів, пр гнення створити с модост тні економіки. все ж через в жсливу роль уніфіков ної б нківсько-фін нсової системи, міжн родних корпор иій тр нсн иіон льні економічні інтереси ст ли домінув $m u$ [14]. роцеси економічної інтегр ції, регіон льного співробітництв т формув ння регіон льних об'єдн нь, що охоплюють суміжні обл сті кр їн, н були особливо великого розм ху в вропі, зн чною мірою зумовивши й геополітичні тенденції до 
міждерж вного зближення, формув ння н дн ціон льних структур. роте трив лість цих тенденцій т кож не можн бсолютизув ти, особливо н тлі зрост ння інтенсивності протилежно спрямов них процесів.

етнополітичній сфері, усупереч монді лістським проект м уніфік ції політичного простору, усе ж провідною є об'єктивн тенденція до формув ння н ціон льних держ в, етнон ціон льних федер цій, етнон ціон льних втономій. окрем , н рост ння хвилі формув ння н ціон льних держ в, етнон ціон льних федер цій, етнон ціон льних втономій, н с мперед у вропі й зії, переконливо підтверджує, що тенденція до відповідності, з одного боку, територі льно-політичної орг ніз иї суч сного cвimy, в жливими скл довими якої є держ вні території, держ вні кордони, і, з іншого,- етногеогр фічної орг ніз ції людств, територі льними підрозділ ми якої $\epsilon$ етнічні території, етнічні межі тощо, м $є$ з кономірний х $p$ ктер $і$ простежується впродовж кількох ост нніх століть [5, с. 45]. одноч с з кономірним є й диференційов ний перебіг етнополітичних процесів у регіон х світу, що особливо помітно виявляється в регіон х 3 втохтонним н селенням т в регіон х переселенського типу. ому з ур хув нням з кономірних тенденцій територі льно-політичного розвитку можн зробити висновок, що тільки систем рівнопр вних н иіон льних держ в $i$ етнон ціон льних федер цій може бути оптим льною моделлю геополітичного світоустроюякн глоб льном рівні, $m \kappa i$ н рівні історично-культурних регіонів.

к с мо, незв ж ючи н різноспрямов ні, проте не вз ємовиключні тенденції, н глоб льному рівні з кономірне утворення $m$ змін цивіліз цій-культур, що є великими історико-геогр фічними р йон ми й охоплюють групи н родів $i \kappa p$ ї, які в ході трив лого історичного розвитку н були деяких спільних рис культури, мент літету, у тому числі геополітичного мислення. ро об'єктивність і з кономірність цього процесу 3 зн ч ло б г то істориків, соціологів т філософів ( . нилевський, . пенглер, . ойнбі, - нтінгтон), хоч з огляду н скл дність феномен цивіліз цій, вони н зив ли різні рушійні сили, тенденції $\mathrm{T}$ перспективи їхнього розвитку.

йоб'єктивніше формув ння культурно-цивіліз ційних типів розкрив . нилевський, визн чивши і суттєві генетичні з с ди цивіліз цій-культур (н род бо споріднені н роди), і основні передумови (необхідність і н явність політичної нез лежності), і рушійні сили розвитку (внутрішня енергія), і оптим льну структуру великих культурно-історичних р йонів (систем н ціон льних держ в чи етнон ціон льних федер цій) [3]. ле у р зі виділення основних рушійних сил формув ння цивіліз цій-культур, окрім етногеогр фічних підст в (н род бо споріднені н роди), потрібно т кож інтегр льно вр ховув ти і в гому роль інших чинників (поширення світових релігій, великодерж вних утворень). голосимо, що цивіліз ції-культури з структурою не $\epsilon$ вузловим $p$ йоном, лише відносною мент льною однорідністю, тому ілюзорними можуть бути підходи щодо творення н основі цивіліз цій-культур н ддерж в, чи, т к би мовити, центр льних держ в, оточених держ в ми-с теліт ми, як це розгляд ють у деяких геополітичних моделях, зокрем , у . нтінгтон [12].

ур хув нням зн чущості походження т еволюції політико-геогр фічних структур, пріоритетності структурно-функціон льних зв'язків, геополітичні дослідження $\epsilon$ н йбільш ефективними н $з$ с д х історичного, у тім числі історично-генетичного т історично-еволюційного, і геоструктурно-функціон льного методологічних підходів. утність історичного підходу в геополітичних дослідженнях поляг є у дет льному відстежув нні процесів з родження і розвитку деякого територі льно-політичного феномен 3 метою виявлення причинно-н слідкових зв'язків у його формув нні 
й розвитку. нше в жливе з вд ння історичного геополітичного н лізу - виявити геогр фічні сліди минулих історичних епох у суч сному геополітичному світоустрої, зв ж ючи н те, що історико-суспільний процес, з слов ми . опчієв , це не лише “еволюція, розвиток і з перечення ст рого, розрив з минулим і творення нового”, й “збереження й перенесення з минулого в суч сне й м йбутнє усього життєзд тного” [11, с. 73]. одноч с структурно-функщіон льний підхід у дослідженні певного територі льно-політичного об'єКт поляг є у визн ченні його внутрішньої орг нізов ності т внутрішніх функціон льних зв'язків, пов'яз ності із зовнішнім середовищем, виявляючи ре льні п р метри геополітичної ситу ції т перспективи іiі под льшого розвитку. бидв ці підходи треб обов'язково поєднув ти, не допуск ючи т ких кр йнощів, як перенесення історичних моделей вирішення геополітичних проблем н цілком відмінний суч сний грунт чи, н вп ки, повне з перечення інерції політичних систем минулого т недооцінюв ння історично-політичних тр дицій, х р ктерне, н прикл д, для . оппер [10].

геополітичній н літиці ефективним може бути і з стосув ння міждисциллін $p$ ного niдxоду, в основі якого - використ ння методичних прийомів і концепту льних з с д інших дисциплін. роте в цьому р зі потрібно бути обережним і коректним щодо використ ння різних н логій т моделей, які сформув лися в інших н ук х, оскільки можливими можуть бути і не зовсім вд лі прикл ди з позичень. окрем , . тцель, провівши н логії між держ вними т біологічними орг нізм ми, спробув в виявити подібності в цикл х їхнього розвитку, проте в підсумку дійшов до дуже сумнівних висновків [4, с. 10]. огляду н вз ємовпливи пр ктики міждерж вних відносин і геополітичних доктрин, ре льні геополітичні процеси і тенденції необхідно вивч ти в єдності з їхнім відобр женням у різних геополітичних моделях. прикл д, дослідження політичного зн чення суч сних глоб льних релігійно-геогр фічних змін треб поєднув ти 3 н лізом тр ктув ння ролі релігійно-геогр фічного чинник в різних геополітичних доктрин х.

вивченні історичних геополітичних процесів (геополітичної історії) основною методологічною проблемою є оцінення зн чення різних рушійних сил розвитку н різних історичних ет п х. ме гіперболіз ція ролі окремих чинників і зумовлюв л в минулому б чення територі льно-політичних змін крізь призму природногеогр фічного, економічного детермінізму, форм ційного м рксистського підходу з його бсолютиз цією кл сової боротьби т ін. ому спроби т кого вузького тр ктув ння історично-геополітичного процесу відобр ж ють певну методологічну обмеженість і однобічно розкрив ють усю скл дність процесів. огляду н це с ме принцип ур хув ння сукупної дї всіх чинників (етнон ціон льного, релігійного, держ внополітичного, економічного т ін.) н різних історичних ет п х може 3 безпечити розуміння мех нізму т вектор еволюції геополітичного середовищ . одноч с об'єктивне оцінення впливу всіх чинників н процеси розвитку н певному історичному ет пі може підтвердити провідну роль одного з них, що, одн к, не д є підст в для висновків про його пріоритетність і н інших ет п х. голосимо, що н ліз сукупної дії геогр фічних чинників може слугув ти методологічною основою дослідження геополітичної орг нізов ності світу не лише в історичному т суч сному спект х,

й у контексті створення прогнозних моделей. ля кожного історичного періоду х р ктерним є свій н бір суперечностей у вз ємин х суб'єктів геополітики, виникнення яких зумовлюють різні рушійні сили, з гострення спричиняє конфліктні ситу ції, у тому числі й воєнні. одноч с у формув нні суперечностей нового ч су, попри 
різном нітність в рі нтів і мех нізмів, простежується домін нтн роль т ких чинників, як неврегульов ність пит нь політичного ст тусу територій, тр нсформ иійні процеси в геокультурній сфері, пр гнення суб'єктів до зміцнення свойх позицій в ієр рхічній структурі держ вно-політичних центрів, яку формують геогр фія полюсів $m$ лідерів впливу, поширення смуг з лежності, конкуренції, протистояння.

одо ролі природного середовищ, то вон, безумовно, виявляється в б г тьох сфер х життєдіяльності суспільств , проте необхідно чітко окреслити, н скільки, які с ме мех нізми впливу, як трив лість і сфер їхньої дії. окрем , вплив геогр фічного довкілля н формув ння територі льної орг ніз ції суспільств м є більше зн чення в моменти різких змін природних умов, коли суспільство змушене пристосовув тись до нових обст вин. тже, дія природних чинників н суспільно-геогр фічні процеси м $\epsilon$ конкретно-історичний і зн чною мірою опосередков ний х р ктер. ому, н прикл д, єдність етносу 3 природою території особливо помітн в гр рному суспільстві і втілюється у тр диційному природокористув нні. переходом н вищий історичний рівень економічних відносин зв'язок природних умов т етносу посл блюється. ноді вплив природного довкілля простежується через велику кількість проміжних причинно-н слідкових зв'язків, тому некоректно пов'язув ти вихідні природні передумови з ост точними результ т ми. сновними мех нізм ми $m$ кого впливу є різн комунік иійн провідність елементів природного середовищ, тр диційне природокористув ння $m$ особливості сприйняття н селенням різних л ндш фтних форм, які своєрідно відобр жеені і в культурно-мент льних особливостях.

голосимо, що вплив одних природних чинників н політичні процеси з розвитком суспільств , комунік цій зменшується, як, н прикл д, рельєфу, інших - земельних чи мінер льних ресурсів - може зрост ти. суч сних умов $x$ i 2 лом розширюються контури природного середовищ, яке безпосередньо чи опосередков но м $є$ дотичність до політики. окрем, у висотному вимірі, 3 огляду н роль ві ції т космічних озброєнь, це стосується вже усієї тмосфери, у широтному - рктики т нт рктики, виняткові претензії н які н поч тку ст. поч л з являти низк держ в. лоб льного, у тому числі й геополітичного, зн чення н були екологічні т клім тичні проблеми.

кремо виділимо методологічні проблеми дослідження геополітичної ситу ції i геополітичного ст новищ кр їни, що зумовлено помітним інерційним впливом p дянських ідеологічних стереотипів, т кож н м г нням перейняти мех нічно, без критичного переосмислення, п р дигми й технології з хідних постмодерністських концепцій розуміння глоб льних процесів, сутності держ ви, н ції тощо. кож неприйнятним $є$ розгляд територі льно-політичних проблем кр їни через призму російських геополітичних проектів (євр зійств, російського п нсл візму), які в розумінні укр їнської проблем тики, н с мперед несприйнятті укр їнської с мобутності, дивовижно поєднують ц рсько-імперські підходи з р дянсько-комуністичними т неоімперськими і н пр ктиці безпосередньо спрямов ні н порушення територі льнополітичної цілісності кр їни. езульт том методологічної недоскон лості в розумінні геополітичної ситу ції в кр їні є низк непр вильних н ст нов, лише окремі прикл ди яких т кі: 1) бсолютиз ція історично-геогр фічних відмінностей, 3 якою іноді н голошують н нібито штучності об'єдн ння регіонів кр їни в меж х єдиної держ вної території і відсутності об'єктивних історично-геогр фічних передумов їі цілісності; 2) гіперболіз ція поліетнічності й полірелігійності кр їни, як т кож з кл д є нерозуміння чинників територі льно-культурної і територі льно-політичної 
цілісності держ ви й уявлення про величезні ім нентні міжрегіон льні суперечності, відт к і обмежені перспективи.

одноч с об'єктивне відтворення усіх історично-геогр фічних передумов з свідчує, що кр їн як держ в м є інтегр ційний (скл дений) х р ктер лише в тому сенсі, що різні їі регіони в минулому були у скл ді різних держ в (т кий с мий історично скл дений х р ктер м є, н прикл д, ольщ, умунія, олг рія т деякі інші), проте 3 основним чинником формув ння європейських держ в, етнон ціон льним, кр їн це цілісн , єдин кр їн , приблизно $95 \%$ держ вної території якої - ре л перев жного розселення держ вотворчої укр їнської етнічної н ції. тому с ме геогр фія укр їнського н роду $m$ його тісні зв'язки з іншими етнічними груп ми в окр їнних ч стин $х$ території є основою геополітичної цілісності кр їни, чого, н ж ль, через методологічну обмеженість $m$ ідеологічну з нг жов ність, не зн $е$ бо не поміч $є$ більшість укр їнського політикуму. кож н голосимо, що в методології укр їнозн вчих досліджень посил ння н н лежність окремих регіонів кр їни до різних у минулому держ в, річкових $б$ сейнів чи б сейнів морів можуть м ти сьогодні, в умов х єдиної держ ви, лише другорядне зн чення, їх не доцільно тр ктув ти як виріш льний ргумент у розгляді перспектив територі льно-політичної цілісності держ ви, особливо з умов етнокультурної консолід ції укр їнської н ції. к с мо етногеогр фічні ре лії не д ють підст в для висновків про з г льнорегіон льну поліетнічність кр їни, дже поліетнічність держ ви, тим більще тї 6 г тон ціон льність, визн ч є не н явність окремих предст вників етнічних груп, множинність ре лів розселення втохтонних етнон ціон льних спільнот $m$ їхня суттєв демогр фічн в г. огляду н це поліетнічний чи двоетнічний х р ктер м ють лише порівняно невеликі ре ли держ вної території кр їни ( рим, івденн есс р бія, онеччин ).

ирішення методологічних проблем є передумовою формув ння методик н лізу різних спектів геополітичної орг ніз ції світу н з с д х використ ння методичного потенці лу геогр фії, політичних, соці льних т економічних н ук. вивченні вужчих г лузевих пит нь (економіко-геополітичних, культурно-геополітичних) пріоритетними є методи відповідних суміжних н укових дисциплін (економічних, культурологічних). одноч с $y$ комплексному н лізі геополітичних ситу цій н йбільш ефективне моделюв ння ролі всіх чинників з використ нням cm тистично-м тем тичних $m$ $\kappa$ ртогр фічного методів.

1. жезінський 3. елик ш хівниця / . жезінський. - в но- р нківськ : ілея , 2000. $-236 \mathrm{c}$.

2. умилев . . тногенез и биосфер емли / . . умилев. - б. : рист лл, 2001. $-640 \mathrm{c}$

3. нилевский . . оссия и вроп / . . нилевский. - . : ниг , 1991. - 76 с.

4. ністрянський . . еополітичні доктрини і підходи: критичний н ліз методології / . . ністрянський. - ьвів : ид вничий центр ім. в н 2003. - $114 \mathrm{c}$

5. ністрянський . . тнополітичн геогр фія кр їни : проблеми теорії, методології, пр ктики / ністрянський. - ьвів : ітопис, 2006. - 490 с.

6. ністрянський . . еополітик / . . ністрянський. - ьвів : імені в н p HK , 2011.-436 c. 
7. ккиндер X. еогр фическ я ось истории / Х. ккиндер // олис. - 1995. № 4. - . 162-169.

8. их льченко . імітроф / . их льченко // олітологічний словник [з ред. . . олов того, . . нтонюк ]. - . : , 2005. - .439-440.

9. олітичн геогр фія і геополітик : н вч. посібник / . . ценко, . . т фійчук, . . p йчевський т ін. - . : ибідь, 2007. - 255 с.

10. опnер . ідкрите суспільство т його вороги : 2 т. / . оппер. - . : снови, 1994. - 444/495 c.

11. опчієв . . успільно-геогр фічні дослідження: методологія, методи, методики / . . опчієв. - дес : стропринт, 2005. - 632 с.

12. нтиингтон . толкновение цивилиз ций / . нтингтон // олис. - 1994. № $1 .-$. 33-48.

13. ымбурский . . оссия - емля 3 еликим имитрофом: цивилиз ция и геополитик / . . . ымбурский. - . : , 1999. - 186 с.

14. ценко . . ег тренди світового господ рств / . . ценко // кр. геогр. журн. - 1998. - № 4. - С. 3-7.

m ття: н дійшл до ред кції 14.01.2014

доопр иьов н 04.03 .2014

прийнят до друку 25.06.2014

\section{CONCEPTUAL AND METHODOLOGICAL PROBLEMS OF GEOPOLITICS AS SCIENTIFIC DISCIPLINE}

\section{Myroslav Dnistryanskyy}

Ivan Franko National University of Lviv, P. Doroshenko Str., 41, UA - 79000 Lviv, Ukraine

Critical analysis of concepts and terminology of geopolitics was made. Paradigm of scientific analysis of global geopolitical processes was proved. The basic modern global political trends were represented. A regularity formation and change of civilizations-cultures were grounded. Significant relationships and dependencies in the geopolitical system in the world were defined. The regular character of the convergence of the territorial organization of political and ethnic areas of the modern world was exposed. Incorrect methodological approaches to the analysis of the geopolitical situation in Ukraine were allocated.

Key words: geopolitics, objective geopolitical analysis, methodology of geopolitics, conceptual foundations of geopolitics, geopolitical trends. 